\title{
Evaluation of the Efficacy of lodophor Disinfection of Walleye and Northern Pike Eggs to Eliminate Viral Hemorrhagic Septicemia Virus
}

\author{
By M.T. Tuttle-Lau', K.A. Phillips ${ }^{2}$ and M.P. Gaikowski ${ }^{1}$
}

\section{Background}

Viral hemorrhagic septicemia virus (VHSv) is a serious fish pathogen that has been responsible for large-scale fish kills in the Great Lakes since 2005 (Elsayed and others, 2006; Lumsden and others, 2007; Groocock and others, 2007; Winton and others, 2007). The virus is a member of the family Rhabdoviridae, which includes other highly virulent fish pathogens such as infectious hematopoietic necrosis and spring viremia of carp virus (Winton and others, 2008), and it is listed by the World Organization for Animal Health as a reportable pathogen (Animal and Plant Health Inspection Service, 2006; World Organization for Animal Health, 2007). The virus causes high mortality and resulting outbreaks have severe economic consequences for aquaculture. Direct losses in aquaculture facilities can occur from quarantines of affected fish, depopulation and disinfection, and facility closures following detection of VHSv (Bebak, 1998).

Genetic analysis of the Great Lakes VHSv isolate indicated that it was distinct from genotypes previously isolated in Europe, North America, Japan, or Korea. It was, therefore, subsequently classified as Genotype IVb (Winton and others, 2008; Bowser, 2009). By 2007, VHSv had been isolated from 25 fish species (for example, muskellunge, Esox masuqinongy, and freshwater drum, Aplodinotus grunniens) from the St. Lawrence River, Lake Ontario, Lake St. Clair, Lake Huron, and Lake Michigan (near Green Bay, Wis.), as well as from inland waters in Michigan, New York, and Wisconsin. Viral hemorrhagic septicemia virus was also isolated from wild muskellunge collected as broodstock from Clear Fork Reservoir, Ohio in 2008 and from sea lamprey, Petromyzon marinus, from northern Lake Huron.

External clinical signs of a VHSv infection include hemorrhaging ("redness") of the skin, swollen abdomen, or exopthalmia ("pop-eye"; fig. 1). Hemorrhages can also be present internally in the liver, spleen, intestines, or musculature (fig. 2).

Outbreaks of VHSv in the Great Lakes raised concerns regarding VHSv introduction to public hatcheries and private fish farms as well as inland waters within and outside the Great Lakes region. In response, the U.S. Department of Agriculture Animal Plant Health Inspection Service (APHIS) implemented an interim rule in October 2006 that restricted the transfer of fish out of Great Lakes States (APHIS, 2006). Species affected

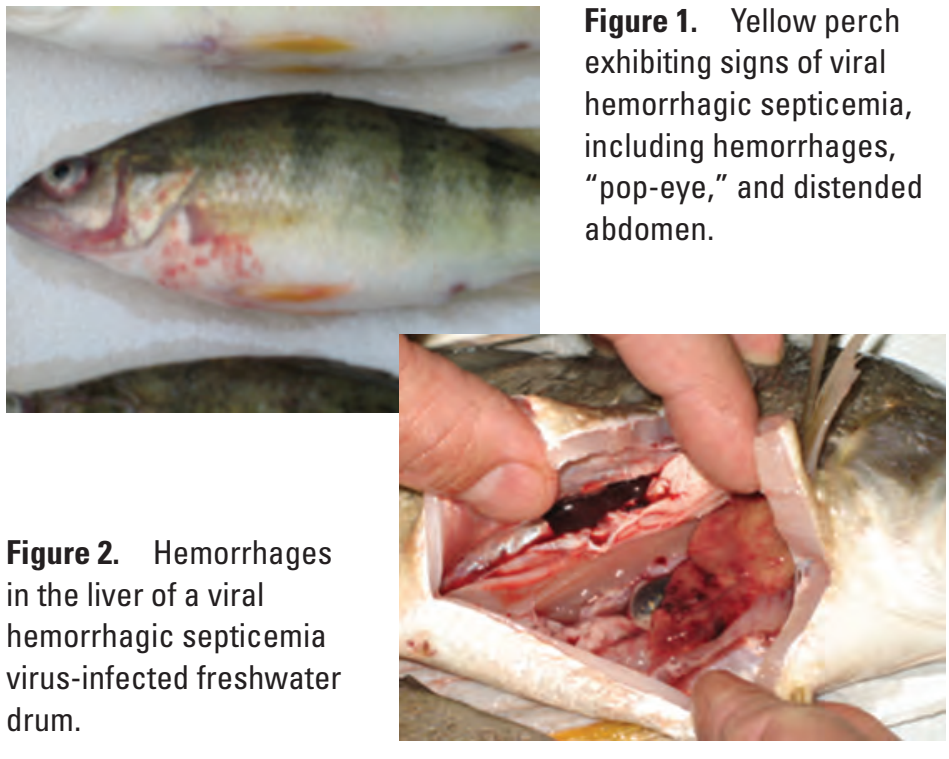

by the APHIS rule included muskellunge, northern pike, Esox lucius, yellow perch, Perca flavescens, walleye, Sander vitreum, round goby, Neogobius melanostomus, and others known to be susceptible to VHSv (Bowser, 2009). The interim rule sought to reduce transmission of VHSv via fish shipments from Great Lakes States to elsewhere in the United States.

Since the 1970s, iodophor disinfection of salmonid eggs has been a standard hatchery practice used to reduce the risk of pathogen transfer through ovarian or seminal fluids during gamete collection ("spawning") operations. This long history of effective use has made iodophor disinfection a leading candidate for reducing VHSv transmission during and after gamete collection from nonsalmonid fishes. However, before iodophor egg disinfection is incorporated as a standard practice in gamete collection from nonsalmonid fishes, the safety and effectiveness needs to be evaluated. The primary objective of this study was to assess the efficacy of iodophor disinfection for eliminating VHSv (strain IVb) from fertilized eggs of walleye and northern pike intentionally challenged with VHSv following egg fertilization. A secondary objective was an assessment of the survival (hatch) of walleye and northern pike eggs following iodophor egg disinfection.

${ }^{1}$ U.S. Geological Survey, Upper Midwest Environmental Sciences Center, La Crosse, Wis.

${ }^{2}$ U.S. Fish and Wildlife Service, La Crosse Fish Health Center, La Crosse, Wis. 


\section{Study Methods}

Adult walleye and northern pike were collected from the Mississippi River near Genoa, Wis. and spawned according to methods described by Piper and others (1982) at the Upper Midwest Environmental Sciences Center (UMESC) by personnel from the U.S. Fish and Wildlife Service (USFWS) Genoa National Fish Hatchery (fig. 3). A 0.6-percent sodium chloride

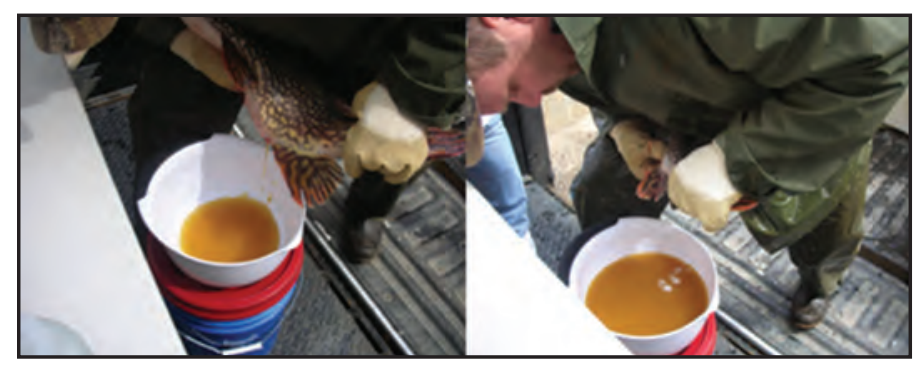

Figure 3. Gamete collection from adult female (left) and male (right) northern pike. Northern pike and walleye were collected from the Mississippi River.

solution was used to activate northern pike sperm, whereas UMESC well water was used to activate walleye sperm. Immediately after sperm activation, fertilized eggs were taken to a laboratory that has controlled access and effluent disinfection. Laboratory effluent was disinfected first by ultraviolet disinfection, then chlorination, then again by ultraviolet disinfection. Eggs were challenged, disinfected, and incubated in the same laboratory. Eggs were challenged at either $10^{5}$ or $10^{8}$ plaqueforming units (PFU) per milliliter (mL). Virus used for this study was initially isolated by the USFWS La Crosse Fish Health Center from emerald shiners, Notropis atherinoides, collected from Lake Erie in 2006. Sequence data provided by the USGS Western Fisheries Research Center in Seattle, Wash. confirmed that the isolate is identical to the Great Lakes strain of VHSv (strain IVb) isolated by Elsayed and others (2006) and Gagne and others (2007). Eggs challenged with VHSv at $10^{5} \mathrm{PFU} / \mathrm{mL}$ were progeny of different brood fish pairings than those challenged at $10^{8} \mathrm{PFU} / \mathrm{mL}$. Walleye egg adhesion was reduced by immersing the eggs in a bentonite solution for approximately $(\sim) 2$ minutes ( $\mathrm{min}$ ) during VHSv challenge. Bentonite was rinsed from the eggs with well water, and then a bentonite-free VHSv challenge solution was added at the appropriate titer. Immediately after challenge, eggs were assigned to one of the four disinfection treatment groups listed in table 1.

Eggs were held in well water for at least 90 min postfertilization, including both the challenge and disinfection periods, before they were distributed to miniature egg jars $(\sim 25 \mathrm{~mL} / \mathrm{jar}$; Rach and others, 1995). The eggs of each species were divided among 48 jars: 12 jars from each of the four disinfection treatment groups, of which 6 jars were from each of the two titer levels. Eggs were maintained in egg jars at about 12 degrees Celsius $\left({ }^{\circ} \mathrm{C}\right)$ until hatch, and no other chemical treatments were applied. Fungus was controlled by increasing water flow to "roll" eggs and by manually removing affected eggs.

Egg and fry samples were collected and the presence or absence of VHSv was determined by culture on epithelioma papulosum cyprini cells incubated at $15^{\circ} \mathrm{C}$ in minimum essential medium with fetal bovine serum added (10 percent final concentration). Triplicate egg samples were collected from each treatment level immediately after VHSv challenge and again before transfer to egg jars. A single egg sample was then collected daily from each egg jar for the first 5 incubation days and then every other day until hatch. Fry were collected once from each egg jar after all viable eggs had hatched. Assays used for determining the presence of VHSv were conducted according to the USFWS and American Fisheries Society-Fish Health Section "Standard Procedures for Aquatic Animal Health Inspections" (2007). Virus titer was determined by use of a modified plaque-assay method described by Batts and others (1991). The probability of hatch versus iodophor treatment assignment was modeled by use of a generalized linear mixed model (Wolfinger and O'Connell, 1993). The effect of iodophor disinfection was modeled as a discrete classification variable, and comparisons were made separately for each species and titer level; treatment levels were judged statistically different if the statistical probability $(P)$ was less than or equal to 0.05 .

Table 1. Iodophor disinfection treatment groups. Disinfection was initiated at 30 minutes after fertilization (immediately after viral challenge), except that disinfection of treatment group 4 was initiated at 90 minutes after fertilization.

[min, minute; ppm, parts per million; , approximately]

\begin{tabular}{lcccc}
\hline $\begin{array}{c}\text { Treatment } \\
\text { group }\end{array}$ & $\begin{array}{c}\text { Iodophor } \\
\text { disinfection }\end{array}$ & $\begin{array}{c}\text { Time initiated } \\
\text { (min postfertilization) }\end{array}$ & $\begin{array}{c}\text { Disinfection duration } \\
\text { (min) }\end{array}$ & $\begin{array}{c}\text { Iodophor } \\
\text { concentration } \\
\text { (ppm) }\end{array}$ \\
\hline 1 (control) & No & NA & NA & 0 \\
2 & Yes & $\sim 30$ & 30 & 60 \\
3 & Yes & $\sim 30$ & 10 & 100 \\
4 & Yes & $\sim 90$ & & 100 \\
\hline
\end{tabular}




\section{Results}

\section{Virus Isolation}

VHSv was not isolated from any iodophor-disinfected treatment group (treatment groups 2-4). However, VHSv was isolated from control eggs (treatment group 1; table 2; fig. 4) immediately after challenge and for up to 4 days after challenge in northern pike eggs challenged at $10^{8} \mathrm{PFU} / \mathrm{mL}$. Virus was not detected in control eggs 1 day postchallenge for either northern pike or walleye eggs challenged at $10^{5} \mathrm{PFU} / \mathrm{mL}$. Virus was not detected in fry of either control (table 2) or iodophor-disinfected treatment groups.

Table 2. Detection of viral hemorrhagic septicemia virus in northern pike and walleye control eggs and fry.

[Detection is expressed in the number of positive samples per number of samples tested. PFU/mL, plaque-forming units per milliliter; NT, not tested]

\begin{tabular}{cccccc}
\hline \multirow{2}{*}{$\begin{array}{c}\text { Day } \\
\text { postchallenge }\end{array}$} & \multicolumn{2}{c}{ Northern pike } & & \multicolumn{2}{c}{ Walleye } \\
\cline { 2 - 3 } \cline { 5 - 6 } & $\mathbf{1 0 ^ { 5 }}$ PFU/mL & $\mathbf{1 0}^{8} \mathbf{P F U} / \mathbf{m L}$ & & $\mathbf{1 0}^{5}$ PFU/mL & $\mathbf{1 0}^{8} \mathbf{P F U} / \mathbf{m L}$ \\
\hline${ }^{1}$ Day 0 & $3 / 3$ & $3 / 3$ & & $2 / 3$ & $3 / 3$ \\
${ }^{2}$ Day 0 & $2 / 3$ & $3 / 3$ & & $2 / 3$ & $3 / 3$ \\
Day 1 & $0 / 6$ & $6 / 6$ & & $0 / 6$ & $2 / 6$ \\
Day 2 & $0 / 6$ & $6 / 6$ & & $\mathrm{NT}$ & $\mathrm{NT}$ \\
Day 3 & $0 / 6$ & $6 / 6$ & & $\mathrm{NT}$ & $\mathrm{NT}$ \\
Day 4 & $0 / 6$ & $4 / 6$ & & $\mathrm{NT}$ & $\mathrm{NT}$ \\
Day 5 & $0 / 6$ & $0 / 6$ & & $\mathrm{NT}$ & $\mathrm{NT}$ \\
Fry & $0 / 6$ & $0 / 6$ & & $0 / 6$ & $0 / 6$ \\
\hline
\end{tabular}

${ }^{1}$ Eggs collected immediately after challenge.

${ }^{2}$ Eggs collected immediatelyafter water hardening

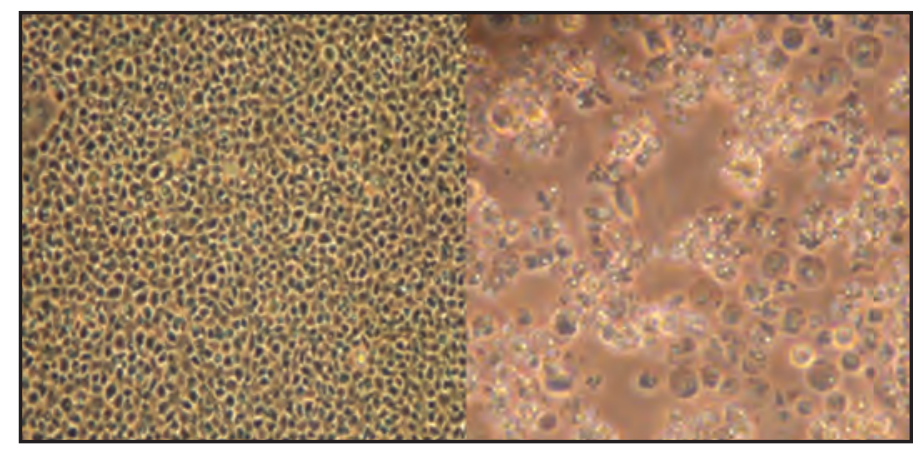

Figure 4. A confluent monolayer of uninfected epithelioma papulosum cyprini cells (left) and viral hemorrhagic septicemia virus, strain IVb-infected epithelioma papulosum cyprini cells (right).

\section{Percentage of Hatch}

Although some iodophor treatments reduced hatch, eggs and fry appeared to develop normally (fig. 5). Iodophor disinfection for 30 or $60 \mathrm{~min}$ (treatment groups 2 and 3) did reduce hatch of walleye and northern pike eggs relative to controls (treatment group 1) and those eggs disinfected for $10 \mathrm{~min}$ at 90-min postfertilization (treatment group 4) in certain cases (table 3). Egg source appeared to explain a substantial amount of the variation in egg hatch; eggs challenged at $10^{5} \mathrm{PFU} / \mathrm{mL}$ were from different brood fish pairings than those challenged at $10^{8} \mathrm{PFU} / \mathrm{mL}$. In both northern pike and walleye, eggs from one set of brood fish appeared to be more sensitive to longer disinfection periods than eggs from the other set of brood fish; for example, northern pike eggs challenged at $10^{5} \mathrm{PFU} / \mathrm{mL}$ and disinfected for 30 or $60 \mathrm{~min}$ had significantly lower hatch than the eggs in the $10^{8} \mathrm{PFU} / \mathrm{mL}$ group.

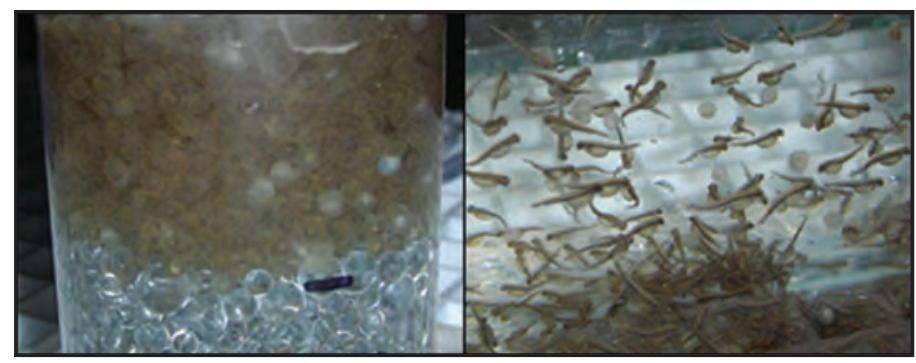

Figure 5. A miniature egg jar containing developing northern pike eggs (left) and hatched northern pike.

Table 3. Percentage hatch of northern pike and walleye eggs challenged with viral hemorrhagic septicemia virus and then disinfected by iodophor disinfection or not disinfected (control).

[Means with the same letter within a column are not significantly different (probability is greater than 0.05 ). PFU/mL, plaque-forming units per milliliter]

\begin{tabular}{lcccccc}
\hline \multirow{2}{*}{$\begin{array}{c}\text { Treatment } \\
\text { group }\end{array}$} & \multicolumn{2}{c}{ Northern pike } & & \multicolumn{2}{c}{ Walleye } \\
\cline { 2 - 3 } \cline { 5 - 6 } \cline { 5 - 6 } & $\mathbf{1 0 ^ { 5 }} \mathbf{P F U} / \mathbf{m L}$ & $\mathbf{1 0 ^ { 8 }} \mathbf{P F U} / \mathbf{m L}$ & & $\mathbf{1 0} \mathbf{1 5 F}^{5} \mathbf{P F L}$ & $\mathbf{1 0 ^ { 8 }} \mathbf{P F U} / \mathbf{m L}$ \\
\hline 1 (control) & $61^{\mathrm{a}}$ & $65^{\mathrm{a}}$ & & $44^{\mathrm{a}}$ & $38^{\mathrm{a}}$ \\
2 & $53^{\mathrm{b}}$ & $67^{\mathrm{a}}$ & & $56^{\mathrm{a}}$ & $5^{\mathrm{b}}$ \\
3 & $49^{\mathrm{b}}$ & $67^{\mathrm{a}}$ & & $19^{\mathrm{b}}$ & $0^{\mathrm{c}}$ \\
4 & $61^{\mathrm{a}}$ & $69^{\mathrm{a}}$ & & $54^{\mathrm{a}}$ & $43^{\mathrm{a}}$ \\
\hline
\end{tabular}

\section{Conclusions}

Egg iodophor disinfection appears to effectively eliminate VHSv (strain IVb) from the surfaces of walleye and northern pike eggs. Although certain iodophor disinfection regimens reduced egg hatch in this study, similar iodophor disinfection regimens applied shortly after fertilization $(\sim 5 \mathrm{~min})$ to walleye eggs in previous studies did not alter egg hatch
(M.P. Gaikowski, USGS, oral communication 2009). Incorporation of iodophor disinfection at 100 parts per million during gamete collection from nonsalmonid fishes immediately (less than $5 \mathrm{~min}$ ) postfertilization for $30 \mathrm{~min}$ or at $90 \mathrm{~min}$ after fertilization for 10 min may reduce VHSv (strain IVb) transmission without affecting egg hatch. 


\section{References}

Animal and Plant Health Inspection Service, 2006, Viral hemorrhagic septicemia in the Great Lakes Region: U.S. Department of Agriculture, Animal and Plant Health Inspection Service Industry Alert, 1 p., accessed November 16, 2009 , at http://www.aphis.usda.gov/publications/animal_health/ content/printable_version/ia_viral_hemorrhagic_septicemia_ vs.pdf

Batts, W.N., Landolt, M.L.. and Winton, J.R., 1991, Inactivation of infectious hematopoietic necrosis virus by low levels of iodine: Applied and Environmental Microbiology, v. 57, no. 5, p. 1379-1385.

Bebak, J., 1998, The importance of biosecurity in intensive culture, in Proceedings of the Second International Conference on Recirculating Aquaculture: Roanoke, Virginia Polytechnic Institute and State University, p. 245-252.

Bowser, P.R., 2009, Fish diseases: Viral hemorrhagic septicemia (VHS): College Park, University of Maryland, Northeastern Regional Aquaculture Center Fact Sheet 201-2009, 7 p.

Elsayed, E., Faisal, M., Thomas, M., Whelan, G., Batts, W., and Winton, J., 2006, Isolation of viral hemorrhagic septicemia virus from muskellunge, Esox masquinongy (Mitchill), in Lake St. Clair, Michigan, USA reveals a new sub-lineage of the North American genotype: Journal of Fish Diseases, v. 29, p. 611-619.

Gagné, N., MacKinnon, A.M., Boston, L., Souter, B., CookVersloot, M., Griffiths, S., and Olivier, G., 2007, Isolation of viral haemorrhagic septicaemia virus from mummichog, stickleback, striped bass and brown trout in eastern Canada: Journal of Fish Diseases, v. 30, p. 213-223.

Groocock, G.H., Getchell, R.G., Wooster, G.A., Britt, K.L., Batts, W.N., Winton, J.R., Casey, R.N., Casey, J.W., and Bowser, P.R., 2007, Detection of viral hemorrhagic septicemia in round gobies in New York State (USA) waters of Lake Ontario and the St. Lawrence River: Diseases of Aquatic Organisms, v. 76, p. 187-192.

\section{Acknowledgements}

Funding was provided by the North Central Regional Aquaculture Center through grant number 2008-38500-19157 from the U.S. Department of Agriculture Cooperative State, Research, Education and Extension Service. The USFWS Genoa National Fish Hatchery obtained adult fish for collection of gametes and provided tremendous support to this study. The iodine used in this study, OVADINE®, was gifted by Western Chemical, Inc., Ferndale, Washington.

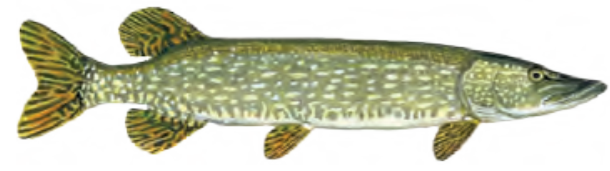

Lumsden, J.S., Morrison, B., Yason, C., Russell, S., Young, K., Yazdanpanah, A., Huber, P., Al-Hussinee, L., Stone, D., and Way, K., 2007, Mortality event in freshwater drum Aplodinotus grunniens from Lake Ontario, Canada, associated with viral haemorrhagic septicemia virus, Type IV: Diseases of Aquatic Organisms, v. 76, p. 99-111.

Piper, R.G., Mc Elwain, I.B., Orme, L.E., McCraren, J.P., Fowler, L.G., and Leonard, J.R., 1982, Fish hatchery management: Washington, D.C., U.S. Department of the Interior, U.S. Fish and Wildlife Service, 517 p.

Rach, J.J., Howe, G.E., and Schreier, T.M., 1995, A miniature hatching system for evaluating chemical treatments on fish eggs: Water Research, v. 29, p. 2103-2107.

US Fish and Wildlife Service and American Fisheries Society, 2007, Suggested procedures for the detection and identification of certain finfish and shellfish pathogens, in Fish Health Section Blue book (2007 ed.): Bethesda, Md., American Fisheries Society-Fish Health Section (CD-R)

Winton, J., Batts, W., and Kurath, G., 2008, Molecular epidemiology of viral memorrhagic septicemia virus in the Great Lakes Region: U.S. Geological Survey Fact Sheet 2008-3003, 4 p. (Also available at: http://wfrc.usgs.gov/pubs/ factsheetpdf/vhsfs2011108.pdf.)

Winton, J., Kurath, G., and Batts, W., 2007, Detection of viral hemorrhagic septicemia virus: U.S. Geological Survey Fact sheet 2007-3055, 4 p. (Also available at http://wfrc.usgs.gov/ pubs/factsheetpdf/vhsfs080807.pdf.)

Wolfinger, R., and O'Connell, M., 1993, Generalized linear mixed models: A pseudo-likelihood approach: Journal of Statistical Computation and Simulation, v. 4, p. 233-243.

World Organization for Animal Health, 2007, Aquatic animal health code: Paris, accessed Nov. 16, 2009, at http://www.oie. int/eng/Normes/fcodelen_chapitre_1.2.3.htm.

\section{Contact Information:}

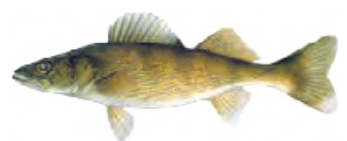

Mark Gaikowski or Maren Tuttle-Lau

U.S. Geological Survey

Upper Midwest Environmental Sciences Center

2630 Fanta Reed Road

La Crosse, WI 54601

email:mgaikowski@usgs.gov; mttuttle@usgs.gov

phone: 608-781-6284; 608-781-6243 